\title{
Izvori Šipuševe knjige Temely xitne tergovine
}

\author{
Vladimir Horvat*, Ivana Klinčićc**
}

\begin{abstract}
Sažetak
Veliko nastojanje zagrebačkog biskupa Maksimilijana Vrhovca za blagostanje Hrvatske i napredak trgovine razvojem kopnenih $i$ vodenih putova svima je poznato i obrađeno u mnogim radovima. Stoga ne začuđuje što je i knjigu Josipa Šipuša Temely xitne tergovine (1796.) Vrhovac dao tiskati u svojoj tiskari. Šipuš se pak pobrinuo da tu temu svestrano prikaže služeći se dostupnim stranim izvorima. U radu su objašnjeni neposredni izvori za Šipuševu knjigu te Šipušev opis stanja gospodarstva u Francuskoj $i$ Velikom Vojvodstvu Toskana.

Ključne riječi: Maksimilijan Vrhovac, Josip Šipuš, Adam Smith, J. A. H. Reimarus, žitna trgovina, blagostanje, siromaštvo, 18. stoljeće
\end{abstract}

\section{Uvod}

U 18. stoljeću siromaštvo je bilo toliko da su ljudi u pojedinim dijelovima Europe umirali od gladi. Zbog vrijednosti žitarica pojedine države uvodile su monopole i restrikcije na trgovinu žitaricama, što je dovelo do neravnomjernog raspoređivanja u pojedinim područjima i posljedično do velikih nestašica i kriza. Stoga su se europski intelektualci aktivno bavili promišljanjem kako riješiti taj problem. Pitanja koja se tiču državnog uređenja, ekonomije, trgovine i sl. promišljala su se sa šireg — filozofskog, etičkog — stajališta.

Godine 1796. u Zagrebu, u Vrhovčevoj tiskari, objavljena je knjiga Temely xitne tergovine, a kao njezin autor naznačen je Josip Šipuš. Knjiga je i posvećena biskupu Vrhovcu: »kak naukov ljubitelju tak naučneh darovniku, ov prvi svojega trsenja trud, na vikovični zahfalnosti uspomenek za vsum podložnostjum istinito i srdčeno alduje, poklanja, daruje pisac« (Šipuš, 1796, [3]). Biskup Maksimilijan Vrhovac i sam je nastojao djelovati kao pokretač gospodarskog života. Poznate su njegove poduzetničke akcije pokušaja uređenja regulacije plovidbe na Kupi i gradnja Lujzinske ceste od Karlovca do riječke luke (1802.-1809.). Ti su projekti

* Prof. dr. sc. Vladimir Horvat, u miru, Fakultet filozofije i religijskih znanosti Sveučilišta u Zagrebu. Adresa: Jordanovac 110, 10000 Zagreb, Hrvatska. E-pošta: vhorvat9@gmail.com

** Doc. dr. sc. Ivana Klinčić, Hrvatski studiji Sveučilišta u Zagrebu. Adresa: Borongajska cesta 83d, 10000 Zagreb, Hrvatska. E-pošta: iklincic@hrstud.hr 
bili usmjereni upravo na poticanje i olakšavanje trgovine žitom (Kolarić, 1995, 439).

Šipuš se u knjizi bavi političkom ekonomijom na način kako se ona promišljala u 18. i kasnije u 19. stoljeću: kroz prizmu trgovine žitaricama kao temeljem državnog napretka. Europa je bivala pogođena razdobljima velikih gladi, koja su sa sobom nosila velik broj ljudskih žrtava, a i izvan tih razdoblja gladi velik je broj Europljana bio pogođen siromaštvom. Potrebno je tu pojasniti zašto su upravo žitarice hrana na koju se oslanjala politička ekonomija. Naime, zrno žitarice u maloj masi sadržava visoku kalorijsku vrijednost, a zbog svojeg suhog stanja lako se dugoročno skladišti s malom opasnosti od propadanja. Spriječiti izvoz žita smatralo se logičnom preventivom gladi. Vladari su nastojali kontrolirati trgovinu žitom tvrdeći da se to čini upravo za dobrobit države. Monopolizacija trgovine žitom u konačnici je koristila vrlo uskomu krugu vladarevih podanika. Takva centralizacija dovodila je do neravnomjernog razvoja zemalja, do upravljanja regijama kao kolonijama te posljedično do povremenih katastrofalnih godina nestašice. Problematika trgovine žitom u 18. stoljeću promišljala se stoga kao primarno etički problem.

U 18. stoljeću javljaju se novi pogledi na trgovinu žitom koji su smatrali da utjecaj države na trgovinu treba biti što manji. Te su ideje teško prodirale u zemlje pod utjecajem apsolutističkih prosvijećenih vladara, koje su provodile merkantilističku ekonomiju potpunog državnog nadzora. Josip Šipuš ipak je te nove struje prikazao na hrvatskom jeziku u svojoj knjizi.

Dva su istaknuta povjesničara ekonomije dala doprinos proučavanju Šipuševe knjige: Vladimir Stipetić i Ivan Erceg. Obojica su u svojim objavljenim radovima isticali velik utjecaj Smithove knjige Blagostanje naroda na Šipuševo izdanje. Vladimir Stipetić dao je i usporedni prikaz Hanžekovićeva hrvatskoga prijevoda Smitha i Šipuševa osuvremenjenog teksta (Stipetić, 2001, 619-625). ${ }^{1}$ Iz njega je vidljivo da je Šipuš vjerno slijedio Smithov rad, pa je Stipetić zaključio da je Šipuš poznavao engleski jezik (Stipetić, 2001, 625). No tri godine kasnije Stipetić dvoji o Šipuševu izvoru za Smithove ideje: »Nije do kraja jasno odakle je Šipuš upoznao Adama Smitha. Je li poznavao engleski original ili je Smitha poznavao na osnovu knjige Reimarusa o žitnoj trgovini koju citira na više mjesta. Ima nekih naznaka (u citiranim tekstovima) da Šipuš citira po sekundarnom izvoru, ali to su tek indicije « (Stipetić, 2004, 47). Stipetić priznaje da nije imao uvid u Reimarusovu knjigu jer ju nije uspio pribaviti unatoč višegodišnjemu traganju (Stipetić, 2004, 47, bilj. 75). ${ }^{2}$ Ivan Erceg zaslužan je jer je 1993. priredio i objavio pretisak Šipuševe knjige te ju na taj način učinio dostupnom javnosti, a u predgovoru je sistematizirao sva dotadašnja znanja, spoznaje i pretpostavke o Josipu Šipušu i njegovu djelu (Erceg, 1993).

1 Stipetić je u poglavlju o Šipušu u navedenoj knjizi prikazao svoje već ranije iznesene tvrdnje (1993a, 1993b, 1994).

2 Nemogućnost da se pribavi Reimarusova knjiga bila je nažalost svima glavna zapreka u sagledavanju izvora za Šipuševu knjige. Upravo zahvaljujući usporedbi Šipuševa teksta s tom knjigom mogli smo konačno u ovom radu ustvrditi kako je Šipuš napisao svoje djelo. 
Iako Vladimir Stipetić na više mjesta, sa stajališta povijesti ekonomije, spominje osobe i tekstove koji se navode u Šipuševoj knjizi, ${ }^{3}$ dosad još nije bilo sistematizirano i kontekstualizirano utvrđeno na koja se sve djela Šipuš referirao niti je istraženo kojim se konkretno izdanjima služio prilikom pisanja svoje knjige. Zato se u našem radu po prvi put utvrđuju neposredni izvori za Šipuševu knjigu Temely xitne trgovine te se daje podroban opis dijela Šipuševe knjige koji se bavi stanjem u Francuskoj i Velikom Vojvodstvu Toskana, i to isključivo u kontekstu tekstova na koje se referira sam Šipuš. Na jednak se način mogu istraživati i druge teme u Šipuševoj knjizi, no to može biti tema i poticaj za neki drugi rad.

Opisujući stanje u Francuskoj i Velikom Vojvodstvu Toskana, Šipuš je citirao izdanja koja zapravo nije imao kod sebe prilikom pisanja jer je slijedio predložak za svoju knjigu. No mi smo i ta izdanja pronašli, kako bismo mogli sagledati cjelokupan kontekst o kojem je Šipuš u svojoj knjizi izvijestio hrvatsku javnost kraja 18. stoljeća.

\section{Izvori za Šipuševu knjigu}

Stručni dio Šipuševe knjige sastoji se od dva dijela: 1. dio Kratkom zadržujuč razloge na kojih trgovina vsake vrsti visi (str. 1-19), 2. dio Osebujne zadržujuč razloge po kojiuh Žitna Trgovina sigurno voditi se može (str. 20-116). U prvom dijelu daje se definicija trgovine, koja se dijeli na veliku i malu. Velika trgovina obavlja se rijekama, kanalima i cestama. Osim toga razlukuje i stranjsku trgovinu, koja odgovara suvremenomu poimanju vanjske trgovine.

Već su naši prethodnici u istraživanju Šipuša utvrdili kako se u njegovoj knjizi više ili manje uspješno donose prijevodi cijelih pasusa Smithove knjige Blagostanje naroda (1776.). Tu već ranije potvrđenu tvrdnju dublje smo istražili s ciljem da pronađemo stvarni Šipušev predložak za Smithovu knjigu.

Nadalje, usporedbom Šipuševe knjige s više djela slične tematike u 18. stoljeću utvrdili smo da mu je drugi predložak bila knjiga Die Freiheit des Getreidehandels (1790.) J. A. H. Reimarusa.

Šipuš nije eksplicitno naveo izvore za svoje tvrdnje i ideje, no priznao je da je knjigu pisao na temelju već postojećih spoznaja: »Donosim javnosti maleni dar, unaprijed pokazujući dobru volju i želju njoj dalje služiti i za njezinu korist raditi, darujući joj ujedno pomoć i usmjerenje ovim svojim napisanim djelom, kojeg ne želim pripisati u potpunosti svojemu vlastitomu razumu i znanju (a time i [našemu] slavnomu i sposobnomu narodu), nego se samo mogu nazivati njegovim sastavljačem i skupljačem koji je na svjetlo iznio i donio uređene spoznaje drugih vrlo uglednih poglavara i učitelja « (Šipuš, 1796, [5-6]). ${ }^{4}$

3 Najdetaljniji je opis u poglavlju Izvori i misaoni utjecaji (Stipetić, 2001, 614-619).

4 Citat smo tu iznimno preveli na hrvatski standardni jezik zbog osebujnog i teško razumljivog Šipuševa izražavanja na hrvatskom jeziku. 
Dakle, Šipuš je knjigu koncipirao u dva dijela, ${ }^{5}$ i to na način da je u prvom dijelu dao prikaz Smithova djela, a u drugom preveo (s mjestimičnim prilagodbama) Reimarusovu knjigu.

Adam Smith (1723.-1790.) bio je na Glasgow College (1750.-1764.) profesor na katedri logike (retorika i književnost) i na katedri moralne filozofije (pravo i političke znanosti). Godine 1759. objavio je prvo svoje djelo Teorija moralnih osjećaja, s kojim je stekao velik ugled. U njemu je iznio stajalište da se svaki čovjek ima pravo koristiti svojim sposobnostima kako god želi, pod uvjetom da ne nanosi štetu drugima ili javnomu interesu. Proveo je oko 16 mjeseci u Francuskoj (1765.-1766.) u kontaktu s cijenjenim francuskim intelektualcima, družeći se najviše s Davidom Humeom. Svoje kapitalno djelo o ekonomiji i gospodarstvu Bogatstvo naroda završio je 1773. te objavio 1776. godine, s originalnim naslovom: An Inquiry into the Nature and Causes of the Wealth of Nations (London, 1776.). Smith smatra da prirođeni nesvjesni egoistični nagon mnogobrojnih pojedinaca, od kojih svaki teži popraviti svoj položaj, stvara ekonomske zakonitosti te samo potpuna sloboda nužno vodi napretku i blagostanju (Hanžeković, 2006, 33).

Smith je smatrao da su vodeni putovi najjeftiniji te da stoga donose i najveći profit. Važnost plovnih putova uvidio je kod nas Maksimilijan Vrhovac te je pozvao francuskog graditelja kanala Charpantirea kako bi se uredila plovnost Kupe do riječke luke, no taj projekt nije se uspio ostvariti, pa se prešlo na gradnju ceste, koja i danas dobro služi.

Prvi dio Šipuševe knjige Kratkom zadržujuč razloge na kojih trgovina vsake vrsti visi (str. 1-19) prijevod je 1. i 3. poglavlja treće knjige Smithova Bogatstva naroda. Ta treća knjiga govori o suodnosu selo-grad, tj. poljodjelstva i manufakture sa stajališta trgovine. Na mjestima gdje Smith daje praktične primjere iz Engleske, Šipuš donosi primjere iz Hrvatske.

Šipuš se nije služio engleskim originalom Smithove knjige, nego vjerojatno njemačkim prijevodima. Pregledom popisa njemačkih izdanja Smithove knjige (Hagemann) utvrdili smo da je na raspolaganju mogao imati dva njemačka prijevoda:

1. Untersuchungen der Natur und Ursachen von Nationalreichthümern, prijevod Johanna Friedricha Schillera (rođak pjesnika Friedricha Schillera) i C. A. Wichmanna, Leipzig: Weidmanns Erben und Reich, 1776.-1778.;

2. Untersuchung über die Natur und die Ursachen des Nationalreichthums, prijevod Christiana Garvea, Breslau: W. G. Korn, 1794.-1796.

Schillerov i Wichmannov prijevod nije pobudio zanimanje kameralista, no nakon Francuske revolucije Garveov prijevod ušao je u sveučilišnu nastavu u Göttingenu i Königsbergu. Sveučilište Kraljevstva Hanover u Göttingenu imalo je mnogo britanskih studenata za koje je trebalo osigurati posebne predavače, a ta su predavanja slušali i njemački studenti. Königsberg je bio trgovačko središte

5 Izuzev opširnoga predgovora, koji se smatra bitnim u jezikoslovnom, a ne ekonomskom kontekstu. 
na kojem su se susretali britanski i pruski proizvodi. Tako su Smithove trgovinske ideje prodrle i u njemačke ekonomske krugove (Hagemann, 2).

Drugi dio Šipuševe knjige većim je dijelom prevedena Reimarusova knjiga Die Freiheit des Getreidehandels nach der Natur und Geschichte (1790.). Johann Albert Heinrich Reimarus (1729.-1814.) bio je njemački liječnik, biolog i teoretičar ekonomije. U svojoj knjizi nastojao je dati prikaz njemu suvremenih ekonomskih trendova iz drugih zemalja, iako su oni bili u suprotnosti s njemačkim merkantilističkim pogledima. U predgovoru je istaknuo da je već prije objavio jednu knjigu slične teme (Die wichtige Frage von der freien Aus- und Einfuhr des Getraides, nach der Natur und Geschichte untersucht, Hamburg, 1771.) te da je ta knjiga bila dobro primljena (Reimarus, 1790, III). Sam se nije bavio trgovinom te su njegovi motivi za pisanje knjige bili od općedruštvenog cilja, što je istaknuo na kraju predgovora: »Ja sam nisam imao nikakvu korist u trgovini. Ali nalazim zadovoljstvo u tom da promatram red u svijetu i lanac ljudske djelatnosti te da sebe gledam kao člana u tom lancu « (Reimarus, 1790, V). ${ }^{6}$

Šipuš je pojedina poglavlja te knjige prevodio doslovno, a pojedine dijelove je preskakao. Mjestimično je davao vlastite uvode i komentare o stanju u hrvatskim krajevima. Čvrsto se držao Reimarusova redoslijeda pa je vrlo jednostavno paralelno pratiti obje knjige i utvrditi što je doslovan prijevod, što je preskočeno, a što je Šipušev autorski dodatak.

Šipuš se mogao služiti dvama njemačkim izdanjima Reimarusove knjige: Hamburg 1790. i Frankfurt — Leipzig 21791. Budući da slijedi paginaciju hamburgškog izdanja, očito se njime služio, iako je na jednom mjestu pogrešno naveo da je to izdanje iz 1791. godine (Šipuš, 1796, 74).

\section{2. Šipuševo poimanje stanja gospodarstva u Francuskoj prije Revolucije}

Od 1. do 8. poglavlja drugog dijela svoje knjige Šipuš paralelno opisuje stanje trgovine i gospodarstva u Engleskoj i Francuskoj. Šipuš je tu preveo nekoliko poglavlja Reimarusove knjige, dodajući mjestimice svoje komentare.

Jedna od najutjecajnijih osoba u Francuskoj u drugoj polovici 18. stoljeća bio je Anne Robert Jacques Turgot (1727.-1781.), ekonomist fiziokrat, političar i suradnik na Diderotovoj Enciklopediji. Bio je ministar financija od 1774. do 1776., te je pokušao spasiti Francusku od bankrota ravnopravnim raspoređivanjem poreznih obveza na sva tri staleža, ukidanjem plemićkih povlastica i liberalizacijom trgovine žitom. Turgot je bio cijenjen u narodu i očekivanja od njegovih reformi bila su velika. No, zbog staleških pritisaka, kralj ga je ubrzo smijenio i reforme su zaustavljene. Turgot je promišljao o pitanjima suodnosa dobara, novca i dobiti i jedan je od začetnika političke ekonomije kako ju razumijevamo danas, o čemu je pisao u djelima Réflexions sur la formation et la distribution des richesses (1766., „Razmišljanja o stvaranju i podjeli bogatstva“); Lettres au contrôleur

6 Za potrebe ovog rada pojedine rečenice i naslove s francuskog i njemačkog preveo je Vladimir Horvat. 
général [l'abbé Terray] sur le commerce de grains (1770., „Pisma o slobodi trgovine žitom").

Iako je postojao cijeli niz francuskih izdanja o liberalizaciji trgovine, Reimarus se (pa posljedično i Šipuš) referirao na samo dvije knjige o trgovini žitom u Francuskoj: Representations aux magistrats (1769.) i Neckerovu Sur la Législation et le commerce des grains (1775.). Reimarusu nije bio poznat autor prve knjige.

Abbé Roubaud, punim imenom Pierre-Joseph-André Roubaud (1730.1792.), bio je utjecajan sudionik rasprava o trgovini žitom u Francuskoj te zagovaratelj fiziokratskih načela političke ekonomije i zalagao se za slobodu trgovine. Bavio se i jezikoslovljem (Nouveaux synonymes français, 1786.), a ostao je zapamćen kao žestoki protivnik robovlasništva (Le Politique indien ou considérations sur les colonies des Indes orientales, 1768.; Histoire générale de l'Asie, de l'Afrique et de l'Amérique, 1771.). Bio je bliski Turgotov suradnik i angažirani širitelj njegovih ideja. Pisao je za Journal de l'agriculture, du commerce et des finances („List za poljoprivredu, trgovinu i financije“), koji je i uređivao od 1765. do 1774. godine. Upravo je on autor citirane knjige Representations aux magistrats, ${ }^{7}$ a čine je sabrani dokumenti, spisi, odluke i pisma povezani sa žitnom aferom.

Iz Roubaudove knjige Šipuš, uz svoj komentar, donosi i citat iz pisma koje je Parlement de Toulouse $e^{8}$ uputio francuskomu kralju Luju XV. 22. prosinca 1768., a tiče se trgovine žitom:

Od davna se je več ta žalostni dogođaj i u francuski zemlji spoznao, kako Parlament Toulouse u jednoj reprežentaciji turobno spominja iz uzroka skončate žitne trgovine $u$ tuđi orsag. Vidjeli smo napuštene farme koje su njihovi vlasnici napustili jer su propali — Smanjeno stanovništvo postaje svaki dan sve jadnije: količina proizvoda smanjuje se svake godine. Doći će vrijeme da jedan od najljepših i najnaprednijih krajeva postane neplodan. Pelda koju, ne daj Bože, da se i na našima orsagima po takih naredbah izpunjuje! ter vindar mnogo spodobe sadašnum stelišom najplodneše strane mađarske zemlje imade (Šipuš, 1796, 35). ${ }^{9}$

Pismo je cjelovito prvi put objavljeno u Representations aux magistrats (Roubaud, 1769, 351).

7 Puni naslov glasi: Representations aux magistrats, Contenant l'exposition raisonnée des fait relatifs à la liberté du commerce des grains, \& les résultats respectifs des Reglemens \& de la liberté, tj. „Prikazi vlastima, koje sadrže razumno izlaganje činjenica koje se odnose na slobodu trgovine žitom i rezultata koji se odnose na propise i slobodu“. U zaglavlju knjižnih stranica naveden je skraćeni naslov Représentations sur la commerce des Grains, tj. „Prikazi o trgovini žitom“ (Roubaud, 1769).

8 Parlement de Toulouse bio je jedan od francuskih pokrajinskih prizivnih sudova (franc. parlement), koji su bili posljednja razina žalbenog procesa u pravosudnom sustavu, a rješavali su tematski širok raspon pravnih okolnosti, od krivičnih slučajeva do građanskih sporova. Najveći broj predmeta odnosio se na oporezivanje. Zakoni koje je donosio kralj za njih nisu bili obvezujući, a svoj pristanak na kraljeve odluke potvrđivali su tako što bi ih objavili. Sudci su bili plemići neovisni od kralja zvani noblesse de robe („plemstvo po odjeći“), za razliku od noblesse d'épée (,plemstvo po maču“, tj. viteško plemstvo). Zbog svoje neovisnosti i sudbene moći bili su utjecajni faktori unutarnje politike. Pred Revoluciju takvih je sudova bilo 13, a raspušteni su 1789. godine.

9 Tekst u kurzivu Šipušev je tekst koji smo za ovu priliku transkribirali, a tekst u normalu prijevod je s francuskog. 
Jacques Necker (1732.-1804.) bio je ministar financija Francuske ${ }^{10} \mathrm{u}$ tri mandata: 1777.-1780.; 1788.-1789. i 1789.-1790. Sva njegova nastojanja da uredi državne financije nisu bila uspješna i on je na toj funkciji 1789. dočekao Francusku revoluciju. Neckerova knjiga Sur la législation et le commerce des grains u prvoj godini objavljivanja 1775. imala je čak tri izdanja, a četvrto izdanje otisnuto je 1776. godine. Do 1787. bila su još najmanje tri francuska izdanja i jedno na talijanskom (Della legislazione e'l commercio de' grani, Napulj, 1780.). Njemačkog i mađarskog prijevoda nije bilo pa je za Šipuša Reimarusova knjiga bila jedini uvid u taj francuski tekst.

Šipuš se na Neckerovo djelo referirao na dva mjesta: 1. „Beskrajna važnost tog viška ideja je na kojoj se ne bi znalo previše zaustavljati."11 Citat je, kako je Šipuš i naznačio, iz 13. poglavlja prvog dijela Neckerove knjige (usp. Necker, 1776, 66); 2. „Česta intervencija vlasti u trgovinu žitom protivna je dobru države — nikad ne nedostaje da se uvlači velik broj neprikladnosti. “12 Iako je Reimarus točno naznačio da je citat složen od dvaju mjesta u Neckerovoj knjizi — prvi dio rečenice (do crtice) iz 12. poglavlja trećeg dijela (usp. Necker, 1776, 285) i drugi dio iz 6. poglavlja četvrtog dijela (usp. Necker, 1776, 367) — Šipuš je naveo samo izvor za prvi dio rečenice.

Iako je Francuska imala mislioce i intelektualce koji su promišljali gospodarstvo na napredan način, u stvarnosti vlasti nisu uspjele provesti te ideje, što je dovelo do Revolucije.

\section{Veliko Vojvodstvo Toskana}

U 10. poglavlju drugog dijela Šipuševe knjige obrađuju se gospodarske okolnosti u Toskani u vrijeme dok je njome upravljao veliki vojvoda Petar Leopold (Šipuš, 1796, 56-61). Toskana je postala pozitivan primjer gospodarskog i civilizacijskog napretka, pa su u drugim europskim zemljama bili česti izvještaji o odlukama i mjerama koje su dovele do tih promjena. Bio je to krajem 18. stoljeća ogledni primjer uspješnosti liberalnih trgovinskih načela. Šipušu je primjer Toskane bio bitan iz najmanje dvaju razloga: Veliko Vojvodstvo Toskana kao malena država lako se može usporediti s Kraljevinom Dalmacijom, Hrvatskom i Slavonijom, a osim toga toskanski veliki vojvoda Petar Leopold kasnije je kratko vrijeme bio i hrvatski kralj. Šipuš je stoga u potpunosti preveo Reimarusovo 17. poglavlje, dodavši mu nešto duži vlastiti uvod. Reimarus svoje izvješće temelji na dva izvora: Dupatyjevu djelu Lettres sur l'Italie, en 1785. (1788.) i tzv. Andreuccijevoj disertaciji.

10 Necker nije mogao biti imenovan ministrom financija jer je bio protestant, pa je formalno imenovan generalnim direktorom financija (franc. directeur général des Finances), a imao je ovlasti ministra financija.

11 »L'imortance infinie de ce superflu est une idée sur laquelle on ne sçauroit trop s'arrêter « (Šipuš, 1796, 38).

12 »L'intervention frequente du Gouvernement dans le commerce des bleds est contraire au bien de l' etat — ne manque jamais d'entrainer un grand nombre d'inconveniens « (Šipuš, 1796, 41). 
Veliki vojvoda Toskane od 1765. do 1790. bio je Petar Leopold (1747.-1792.), treći sin Marije Terezije i Franje Stjepana Lotarinškog. Preselivši se u toskansku prijestolnicu Firencu, Petar Leopold posvetio se gospodarskomu i socijalnomu napretku, iako nije imao povjerenje svojih toskanskih podložnika. Njegovoj gospodarskoj politici znatno je pomoglo i to što nije imao troškove održavanja vojske. U svojoj malenoj državi proveo je humane socijalne reforme prvi puta viđene u modernoj povijesti Europe: ukinuo je smrtnu kaznu i dao uništiti sve sprave za njezino izvršenje, poticao je preodgoj mladih delikvenata, donio je zakon o mentalnim bolestima koji je osiguravao humano postupanje s bolesnicima, zabranio je torturu kao istražno sredstvo i dr. Nakon smrti brata Josipa II. 1790. preuzeo je austrijsku krunu pod imenom Leopold II. te ukinuo sve bratove reforme osim Patenta o vjerskoj toleranciji i Patenta o ukidanju kmetstva. Umro je iznenada 1792. pa su se pojavile sumnje da je bio otrovan.

U Firenci je u lipnju 1753. osnovana Accademia dei Georgofili ${ }^{13}$ s ciljem promocije zemljoposjedništva i poljoprivrednog napretka, a djelovala je pod motom prosperitati publicae augenda (,povećati bogatstvo naroda“). Akademija Georgofili djelovala je pod protekcijom velikog vojvode Petra Leopolda i imala je znatan utjecaj na vladareve gospodarske odluke. Godine 1771. Akademija Georgofili dodijelila je novčanu nagradu za disertaciju De' mezzi per impiegre $i$ mendichi in vantaggio dell' Agricoltura, e delle Arti („O načinima zapošljavanja prosjaka u korist poljoprivrede i obrta"). Ta je disertacija objavljena iste godine, a kao autor je naveden Luigi Andreucci »cancelliere del Tribunale frumentario di Siena «. Na naslovnici nema mjesta ni godine izdanja, nego još samo obavijest o nagradi. ${ }^{14}$ No pravi autor knjige je Michele Ciani (oko 1720. — oko 1815.), odvjetnik s posebnim interesom za poljoprivredno-ekonomske teme, koji je od 13. prosinca 1753. bio član Akademije Georgofili, a protivio se merkantilističkoj politici koja je regije tretirala kao kolonije te tako onemogućavala njihov napredak (Pii).

Disertacija je imala velik odjek izvan Toskane, no, budući da je potpisana pseudonimom, obično se navodila kao „Andreuccijeva disertacija“, a tako je imenuje i Raimarus, te naravno i Šipuš. Iste je 1771. godine ta disertacija opisana u časopisu L'observateur françois a Londres ${ }^{15}$ u 27. pismu, u kojem se prepričava, mjestimično s prijevodima talijanskog izvornika na francuski, sadržaj disertacije, što se i najavljuje u uvodu: »O načinu kako pristupati siromasima kao prosjacima. Izvadak jedne rasprave koju je nedavno objavio jedan Talijan o tom predmetu, u kojem on pripovijeda što je učinio veliki vojvoda Toskane u korist poljoprivrede i trgovine u svojoj državi« (L'observateur, 1771, 368). Cjeloviti sadržaj disertacije

13 Georgofil, grč. „koji voli zemljoradnju“.

14 »Opera che nella Adunanza del dì 6. Marzo 1771. della Accademia di Agricoltura di Firenze fu giudicata meritevole del solito premio della Medaglia di Oro del valore di Zecchini venticinque (Ciani, 1771).

15 L'Observateur français à Londres ou Lettres sur l'Etat présent de l'Angleterre relativement à ses forces, à son commerce et à ses mours, tj. „Francuski promatrač u Londonu ili Pisma o stanju Engleske i drugih zemalja Europe, o njihovoj politici, snagama, trgovini, literaturi i običajima“, časopis je na francuskom jeziku, kojemu je na naslovnici istaknuto da izlazi u Parizu i Londonu, a izlazio je dvaput mjesečno od 1769. do 1773. godine (Fabre). 
preveden na francuski objavljen je u časopisu Annales Belgeques ${ }^{16} 1772$. godine. Na taj prijevod pozvao se Reimarus (Reimarus, 1790, 48, bilj. 26), a Šipuš je od njega preuzeo francuski prijevod citata u bilješci: »Depuis la loi qui a etabli en $1776^{17}$ la liberte du Commerce des grains, la Toscane en a recuelli beaucoup plus, qu'elle ne faisoit auparavant. A peine en avoit elle suffisamment pour la subsistance des ses habitans: presentement son superflue est devenu pour elle un objet important de Commerce avec l'etranger, qui peutetre évalué a plus de 1500000 Sacs par an «18 (Šipuš, 1796, 56-57).

O toskanskom gospodarskom napretku pisao je i Charles-Marguerite-JeanBaptiste Mercier Dupaty (1746. - 1788.), pravnik i sudac prizivnog suda u Bordeauxu (franc. Parlement de Bordeaux). U Francuskoj je njegova knjiga Lettres sur l'Italie, en 1785. doživjela velik uspjeh, a prevedena je i na njemački (Briefe über Italien vom Jahr 1785, Mainz, 1790.). U Rimu je pak stavljena na Index. Dupaty je o liberalnim trgovinskim okolnostima koje je Toskani osigurao veliki vojvoda te o pozitivnim posljedicama takve politike na razvoj i prosperitet pisao u 25. i 26. pismu (Dupaty, 1788, 111-118). Šipuš je iz Reimarusove knjige prenio na hrvatskom veći odlomak 26. pisma (Reimarus, 1790, 46-47) - to je u Dupatyjevoj knjizi dio od »Un si bon effet [...]« do »et chaque pas la fortifie« (Dupaty, 1788, 121-123).

Šipuš je u bilješci od Reimarusa preuzeo i jedan talijanski tekst o toskanskim prilikama: »Ragiomento sul Comercio dela Toskana, Fiorenza 1781. § 14. „Le savissime leggi frumentarie (de 14 Sett. 1774. de 24 Aug. 1775, de 7 Marzo 1778) hanno di subito ravvivata in Toscana la languente cultura de' grani, e si e veduta destinata alla sementa tanta terra, ingombrata finora della quasi sterile quercia.“" (Šipuš, 1796, 57). Riječ je o knjizi talijanskog ekonomista i književnika Giuseppea Sarchianija (1745.-1821) Ragionamento sul commercio arti e manifatture della Toscana („Obrazloženje o trgovinskoj umjetnosti i manufakturi u Toscani“), no Šipuš nije u potpunosti točno prepisao podatke iz Reimarusove bilješke (usp. Reimarus, 1790, 48). Rezultat je taj da se Šipušev prijepis ne poklapa s izvornim tekstom jer su izostavljani dijelovi rečenice, a tekst bilješke premješten je ispred samog navoda (usp. Sarchiani, 1781, 120).

Osim već spomenutih izdanja koja su se kod Šipuša našla Reimarusovim posredstvom, Šipuš donosi i citat iz časopisa Ephemeriden der Menschheit, ${ }^{19}$ referira-

16 Annales Belgeques mjesečna je revija koja je izlazila od 1771. do 1776. u Amsterdamu, a sadržavala je novosti iz svijeta, iz različitih kraljevstva, o njihovim politikama, trgovini, napretku agrikulture, znanosti, umjetnosti i novih otkrića (Sgard i Van Strien). Više o tom časopisu v. Vliet, 2001.

17 Slovna pogreška kod Šipuša. Treba biti: 1766.

18 Prijevod: „Prema zakonu koji je 1766. utvrdio slobodu trgovine žitom, Toskana je primila mnogo više žita nego što je učinila prije. Jedva je imala dovoljno za uzdržavanje svojih stanovnika. Sada je njezin višak postao za nju velik predmet trgovine s inozemstvom, koji može biti procijenjen na više od 1,500.000 vreća na godinu.“

19 Ephemeriden der Menschheit, oder Bibliothek der Sittenlehre und der Politik („Efemeride čovječanstva, ili knjižnica morala i politike“) časopis je koji je izlazio od 1776. do 1782. godine, a dio je rastuće popularnosti specijaliziranih periodičkih izdanja koja su se bavila pitanjima gospodarskoga razvoja (Cole i Kipp, 2003, 964). 
jući se vrlo površno na sljedeći način: »Siehe Ephemeriden der Menschheit vom Jahr 1775 \& 1776. Landwirthschaftliche Versuche eines Toskanischen Pfarrers. Ner B. S. 81 \& S.« Šipuš je tu zapravo preveo Reimarusov citat anonimnog autora teksta Geschichte der toscanischen Gesetzgebung unter der Regierung des itzigen Großherzogs königl. Hoheit („Povijest toskanskog zakonodavstva u vrijeme vladavine velikog vojvode Njegove Kraljevske Visosti“") koji je zaista objavljen u spomenutom časopisu (V. An., 1776). No i to je već sekundarni izvor, jer je taj tekst preuzet iz knjige Landwirthschaftliche Versuche eines Toskanischen Pfarrers (Firenca, 1775), ${ }^{20}$ a Reimarus upućuje još i na jedno izdanje iz 1786.: »S. auch einen Brief aus Florenz das. 1786. S. 91. u. f.« (Reimarus, 1790, 48).

Reimarusovo poglavlje o Toskani Šipušu je očito bilo izuzetno važno. Preveo ga je u potpunosti te prenio i svu referiranu literaturu. Mišljenja smo da je Šipuš u Toskani nalazio paralele s Kraljevinom Dalmacijom, Hrvatskom i Slavonijom. Te dvije malene državice imale su na prvi pogled sličan status u habsburškom imperiju, no Hrvatska je politički bila u daleko nepovoljnijem položaju. Osim što je kroz Hrvatsku prolazila Vojna granica, politički model banskog namjesništva nosio je svoje administrativne komplikacije. Istovremeno toskanski veliki vojvoda Petar Leopold vladao je neovisno od svojeg brata austrijskog kralja Josipa II. te je Toskani mogao osigurati bolje gospodarske preduvjete.

\section{Zaključak}

Tema trgovine žitom u 18. stoljeću bila je jedna od najvažnijih političkih i etičkih tema. Gotovo svi zapadnoeuropski mislioci bavili su se njome ili barem doticali tu problematiku.

U Hrvatskoj je na unaprjeđenju gospodarskih prilika ustrajno radio zagrebački biskup Maksimilijan Vrhovac, koji je bio svjestan da su preduvjet trgovine i gospodarskog razvoja ceste i plovni putovi, pa je pokušao organizirati uređivanje plovnosti Kupe do Rijeke, umjesto čega se kasnije izgradila Lujzinska cesta, koja i danas služi. Vrhovac je i na mnoge druge načine nastojao poboljšati hrvatske ekonomske prilike, što je bilo vrlo teško jer je upravni centar u Beču nastojao Hrvatskom upravljati kao kolonijom, pa su planirana ulaganja u infrastrukturu trebala koristiti centralnim interesima. Stoga je jasno zašto je Šipuševa knjiga o liberalnim trgovinskim načelima tiskana upravo u Vrhovčevoj tiskari.

U stvaranju knjige Šipuš se služio dvama neposrednim izvorima: njemačkih prijevodom Bogatstva naroda Adama Smitha koji je načinio Christian Garve (Breslau, 1794-1796) te prvim izdanjem Die Freiheit des Getreidehandels J. A. H. Reimarusa (Hamburg, 1790). Šipuš je doslovno prevodio cijele odlomke svojih predložaka preuzimajući čak i reference. U njegovo vrijeme takvo se prevođenje i dopunjavanje nije smatralo plagijatom, nego autorskim djelom, pa je Šipuš knji-

20 To se izdanje spominje kasnije u jednoj bibliografiji pod nešto drukčijim naslovom: »Ebendaselbst. B. III. 1776. S. 80. Landwirthschaftlichen Versuche eines Pfarrers in Toskana. Florenz 1775. 8.« (Soden, 1828, 226). 
gu potpisao svojim imenom kao autor. Posredstvom Reimarusove knjige uputio je na cijeli niz izdanja koja su se bavila problematikom trgovine žitom, a objavljena su u različitim europskim zemljama: Francuskoj, Italiji, Njemačkoj, Danskoj i Nizozemskoj. Tako je Šipuš dao hrvatskim čitateljima krajem 18. stoljeća opširan uvid u tematiku i pregled relevantne europske literature o gospodarskim i etičkim okolnostima trgovine žitom.

Šipuš je u trgovinskim i ekonomskim prilikama u naprednim europskim zemljama tražio način kako poboljšati i unaprijediti stanje u hrvatskim zemljama. U radu smo opisali dva primjera iz Šipuševe knjige: Francusku i Toskanu. Francuska je bila primjer zemlje u kojoj se, uza sva nastojanja i društveni angažman pojedinaca, liberalizacija tržišta nije uspjela postići, gospodarstvo je propadalo i narod je tražio promjene na bolje u revoluciji. Toskana je s druge strane bila primjer države u kojoj je sam vladar uveo liberalne trgovinske propise te tako omogućio gospodarski razvoj. Šipuš je u svojim komentarima ta iskustva nastojao primijeniti na stanje u Trojednoj Kraljevini, a to što je pisao na hrvatskom jeziku pokazuje da je smatrao važnim da te informacije dođu do što širega kruga ljudi.

\section{Literatura:}

Anon. (1776). Geschichte der toscanischen Gesetzgebung unter der Regierung des itzigen Großherzogs königl. Hoheit. Ephemeriden der Menschheit, oder Bibliothek der Sittenlehre und der Politik, 7, 73-104.

Ciani, Michele (1771). De' mezzi per impiegre i mendichi in vantaggio dell' Agricoltura, e delle Arti: Dissertazione dell' Eccelentis. Sig. Dottore Luigi Andreucci cancelliere del tribunale frumentario de Siena. [Firenca.]

Cole, Arthur H.; Kipp, Laurence J. (2003). Economics Literature and Periodicals. Encyclopedia of Library and Information Science. Vol. 2. (Ed. Miriam A. Drake) New York — Basel: Marcel Dekker, Inc. Str. 958-971.

Dupaty, Jean-Baptiste Mercier (1788). Lettres sur l'Italie, en 1785. Knj. 1-2. Rim — Pariz.

Erceg, Ivan (1993). Prilog za razumijevanje Šipušova djela. Josip Šipuš: Temelj žitne trgovine (str. 5-37). Karlovac: Matica hrvatska.

Erceg, Ivan (1997). Povodom dvjesta godina Šipuševa gospodarsko-povijesnog djela. Ekonomski pogled, 48(1), 81-85).

Fabre, Madeleine. L'Observateur français à Londres (1769-1773). Dictionnaire des journaux 1600-1789. URL: http://dictionnaire-journaux.gazettes18e.fr/journal/1076-lobservateur-francais-londres (20.06.2016.)

Hagemann, Harald. German Editions of Adam Smith's Wealth of Nations. University of Hohenheim. URL: http://eet.pixel-online.org/files/research_papers/GE/German $\% 20$ editions $\% 20 \mathrm{of} \% 20$ Smith's $\% 20$ Wealth\%20of\%20Nations.pdf (25.06.2016.)

Hanžeković, Marijan (2006). Predgovor. Adam Smith: Istraživanje prirode i uzroka bogatstva naroda (str. 13-33). Zagreb: Masmedia.

Kolarić, Juraj (1995). Maksimilijan Vrhovac. Zagrebački biskupi i nadbiskupi (str. 427445). Zagreb: Školska knjiga.

L'observateur (1771). L'observateur françois a Londres, ou lettres sur l'état présent de l'angleterre: Relativement à ses forces, à son commerce \& à ses moeurs: Avec des Notes sur les Pariers Anglois, \& des Remarques historiques, crit ques \& politiques de l'Editeur. London - Paris: Chez. P. Fr. Gueffier. 
Necker, Jacques (1775). Sur la législation et le commerce des grains. Pariz.

Reimarus, Johann Albert Heinrich (1790). Die Freiheit des Getreidehandels nach der Natur und Geschichte erwogen von J. A. H Reimarus. M. D. Hamburg: verlegt von Carl Ernst Bohn. Š21791. Frankfurt — Leipzig.Ć

Pii, Eluggero. Ciani, Michaele. Dizionario biografico, Enciclopedia Italiana di Scienze, Lettere ed Arti. Rim: Istituto Giovanni Treccani - Istituto della Enciclopedia Italiana. URL: http://www.treccani.it/enciclopedia/michele-ciani_(Dizionario-Biografico)/ (18.06.2016.)

Roubaud, Pierre-Joseph-André (1769). Representations aux magistrats.

Sarchiani, Giuseppe (1781). Ragionamento sul commercio arti e manifatture della Toscana. Firenca: Nella Stamperia Stecchi e del vivo.

Sgard, Jean; Van Strien, Kees. Annales Belgiques (1771-1776). Dictionnaire des journaux 1600-1789. URL: http://dictionnaire-journaux.gazettes18e.fr/journal/0108a-annales-belgiques (20.06.2016.)

Smith, Adam (2006). Istraživanje prirode i uzroka bogatstva naroda. Zagreb: Masmedia.

Soden, Julius (1828). Die annonarische Gesetzgebung. Versuch eines Systems über den Getraidhandel und die Gesetze, nach welchen die Staatsverwaltungin Absicht des Getraides zu handeln hat. Nebst einer annonarischen Bibliothek. Nürnberg: Bey Riegel und Wiessner.

Stipetić, Vladimir (1993a). Josip Šipuš prvi hrvatski pisac klasične političke ekonomije. Acta historico-oeconomica, 20(1), 145-163.

Stipetić, Vladimir (1994). Josip Šipuš prvi hrvatski pobornik Adama Smitha prije 200 godina. Računovodstvo, revizija i financije, 4(7), 136-139.

Stipetić, Vladimir (1993b). Prvi hrvatski pisac klasične političke ekonomije: Pretisak knjige Josipa Šipuša Temelj žitne trgovine. Matica hrvatska. Karlovac, 1993. Forum: Mjesečnik Razreda za književnost Hrvatske akademije znanosti i umjetnosti, 32(10-12), 828-847.

Stipetić, Vladimir (2001). Povijest hrvatske ekonomske misli: (1298.-1847.) Zagreb: Golden marketing.

Stipetić, Vladimir (2004). Šipuševa knjiga Temelj žitne trgovine u povijesti ekonomske misli. Josip Šipuš. Temelj zitne trgovine (str. 9-63). Zagreb: Dom i svijet — Ekonomski fakultet Sveučilištanu Zagrebu.

Šipuš, Josip (1796). Temely xitne tergovine polag narave dogacsajev razborito po Joseff Sipus Horvatsanu karlovacskome. Zagreb: pretiszkano vu czes. kralyevsz. szlob. biskupsz. stamparii.

Vliet, Rietje van (2001). Annales Belgiques (1772-1776): conservatief-verlichte ideeën over macht en gezag. Tijdschrift voor Tijdschriftstudies, 9, 25-33. DOI: http://doi. org/10.18352/ts.142 (20.06.2016.) 


\title{
Literary Sources for Šipuš's Book Temely xitne tergovine
}

\author{
Vladimir Horvat*, Ivana Klinčić***
}

\section{Summary}

Wheat trade was one of the most crucial political and ethical topics of the 18th century. Nearly all Western European thinkers dealt with the issue or at least touched upon it. The Bishop of Zagreb Maksimilijan Vrhovac persevered in promoting economic opportunities in Croatia and, being aware that roads and navigable waterways are a prerequisite for trade and economic growth, he endeavoured to organise the development of a navigable waterway on the Kupa River as far as Rijeka, instead of which the road Lujzinska cesta was later constructed and which is still in use today.Vrhovac also strived in many other ways to improve economic opportunities in Croatia which was an exceedingly difficult task since the administrative centre in Vienna attempted to govern Croatia as though she were its colony. Therefore, all infrastructure investments which were planned were intended to benefit the interests of the adminstrative centre. Thus it is evident why Šipuš's book on liberal trade principles was printed by none other than Vrhovec's printing office.

When writing his book, Šipuš availed himself of two immediate sources: the German translation by Christian Garve of Adam Smith's The Wealth of Nations (Breslau, 1794-1796) and the first edition of Die Freiheit des Getreidehandels by J. A. H. Reimarus (Hamburg, 1790). Entire paragraphs of Šipušs templates were his literal translations and even the same references were used. In those times, translation and supplementation of this sort were not considered plagiarism, but rather the work of the writer, therefore Šipuš published the book under his own name as the author. Reimarus's book was a means through which he pointed to a series of publications dealing with the issue of wheat trade - books which were published in various European countries such as France, Italy, Germany, Denmark and the Netherlands. In this way Šipuš provided Croatian readers of the end of the 18th century with a broad insight into the topic, as well as with a survey of relevant European literature on the set of economic and ethical circumstances surrounding wheat trade.

By observing trade and economic opportunities among advanced European countries, Sipuš searched for ways to advance and better the situation in Croatian lands. The paper describes two cases from Šipuš's book, namely France and Tuscany. France was an example of a country which, despite the endeavours and social involvement of individuals, did not achieve a liberalization of the market: the economy was failing and people were demanding change for the better through revolution. Tuscany, on the other hand, was an illustration of a country in which the ruler himself introduced liberal trade regulations and thus made economic development possible. In his comments Šipuš endeavoured to apply these experiences to the situation in the Triune Kingdom of Dalmatia, Croatia and Slavonia. The fact that he wrote in the Croatian language indicates that he considered it important for the information to reach a broader circle of people.

Key words: Maksimilijan Vrhovac, Josip Šipuš, Adam Smith, J. A. H. Reimarus, wheat trade, prosperity, poverty, 18th century

* Vladimir Horvat, Ph.D., Full Professor — Retired, Faculty of Philosophy and Religious Sciences, University of Zagreb. Address: Jordanovac 110, 10000 Zagreb, Croatia. E-mail: vhorvat9@gmail.com

** Ivana Klinčić, Ph.D., Assistant Professor, Croatian Studies, University of Zagreb. Address: Borongajska cesta 83d, 10000 Zagreb, Croatia. E-mail: iklincic@hrstud.hr 